\title{
PERSEPSI SISWA DAN GURU TERHADAP PENGGUNAAN LABORATORIUM VIRTUAL DALAM PEMBELAJARAN FISIKA
}

\author{
A Nurwahidah ${ }^{1}$, WN Qolbi ${ }^{1}$, RM Putra $^{1}$, SN Muhajir ${ }^{1}$ \\ ${ }^{1}$ Program Studi Pendidikan Fisika, Fakultas Pendidikan Islam dan Keguruan \\ Universitas Garut, Indonesia \\ J1. Raya Samarang No. 52A, Garut. \\ E-mail: afifahnurwahidah01@gmail.com
}

\begin{abstract}
Abstrak
Kegiatan belajar mengajar seketika diberhentikan dan dialihkan menjadi sistem belajar online akibat pandemi. Tidak mudah untuk sebagian orang atau lembaga untuk menyesuaikan sistem pembelajaran dengan keadaan. Namun disamping itu teknologi berkembang dengan sangat pesat, masyarakat pun mulai beradaptasi dengan keadaan dan mulai mengembangkan, memanfaatkan teknologi yang ada. Contohnya dalam pembelajaran fisika, metode pembelajaran saintifik dan juga prosedur kerja ilmiah yang seharusnya dilakukan secara langsung kini mulai dilakukan secara online juga. Laboratorium virtual menjadi salah satu alternatif untuk bisa melaksanakan praktikum. Banyak pro dan kontra yang terjadi di masyarakat mengenai penggunaan Laboratorium Virtual ini, terlebih mereka yang masih kekurangan fasilitas dan proses akses internet yang kurang terjangkau. Penelitian ini bertujuan untuk menggali dan mengkaji respons komponen pendidikan seperti siswa dan guru dalam Penggunaan Laboratorium Virtual di sekolah. Sehingga memberikan gambaran nyata sebagai acuan untuk pemilihan solusi bagi lapisan masyarakat yang paling terdampak akibat pandemik. Penelitian yang digunakan adalah penelitian kualitatif deskriptif. Penelitian ini menggunakan teknik pengumpulan data sekunder, Dengan instrumen penyebaran angket online kepada siswa dan guru fisika di tingkat SMA sampai universitas, Dengan topik pertanyaan penggunaan laboratorium virtual. Data hasil survei digunakan sebagai acuan untuk mencari solusi dari permasalahan metode pembelajaran dan praktikum fisika di era Pandemi.
\end{abstract}

Kata kunci: pandemi, pendidikan, laboratorium virtual

\section{Pendahuluan}

Pada awal tahun 2020 semua negara di dunia dikejutkan oleh wabah Coronavirus Disease (Covid-19) yang sampai saat ini masih terjadi, virus ini sangat berpengaruh pada kehidupan manusia. Sehingga pemerintah melakukan berbagai macam kebijakan untuk meminimalkan penularan covid-19 salah satunya melakukan Pembatasan sosial Berskala Besar (PBB), memberlakukan Protokol Kesehatan (ProKes) dan diadakannya Pemberlakuan Pembatasan Kegiatan Masyarakat (PPKM) hingga berbagai level.

Wabah Covid-19 ini terus merebak, tepat pada bulan Maret 2020 wabah Covid-19 ini masuk ke negara Indonesia. Sehingga berdampak pada berbagai sektor, khususnya pada sektor Pendidikan di Indonesia (Tim Kerja Kementerian Dalam Negeri,2020). Covid-19 telah menjadi suatu masalah besar bagi seluruh warga di dunia, terutama di Negara Indonesia. Dengan mewabahnya virus ini sangat mempengaruhi berbagai sektor terpenting di Indonesia yaitu salah satunya pada sektor Pendidikan (Napsawati,2020). Pemerintah Indonesia telah memberikan kebijakan untuk mengurangi kegiatan yang melibatkan banyak orang berkerumun seperti sekolah, bekerja dan lainnya. 
Kondisi ini membuat Menteri Pendidikan di Indonesia harus melakukan intervensi untuk menyelamatkan Pendidikan agar tetap berjalan meskipun ada keterbatasan. Intervensi yang didapatkan yaitu dengan metode pembelajaran jarak jauh(PJJ) atau sering disebut dengan pembelajaran daring. Semua lapisan masyarakat perlu menyadari akan perubahan yang tidak dapat dihindari (Muhajir, 2021). M. Tetapi dalam pembelajaran daring ini akan adanya banyak hambatan dalam melaksanakannya, termasuk dalam melaksanakan praktikum fisika dalam keadaan jarak jauh. Pembelajaran daring menjadi metode alternatif di era pandemi. Banyak aplikasi digunakan sebagai media pembelajaran daring diantaranya GCR, Zoom, Google Meet, LMS dan lain-lain. Hal tersebut dilakukan untuk meningkatkan kualitas belajar siswa, walaupun pembelajaran dilakukan tidak seperti biasanya. Kegiatan praktikum virtual juga menjadi salah satu upaya untuk menjalankan pembelajaran secara daring. Dimana dalam proses pembelajaran fisika pastinya membutuhkan praktikum untuk lebih memahami materi-materi dalam pembelajaran fisika baik di sekolah menengah ataupun di tingkat perguruan tinggi. Praktikum virtual juga adalah sebuah upaya untuk meningkatkan motivasi, pemahaman, dan keterampilan siswa (Putri,A; Muslim,M; Wiyono, K, 2018). Tentu saja semua proses pengupayaan tersebut adalah upaya kita dalam menjalankan amanah pendidikan secara baik di tengah Pandemi covid-19 yang hingga kini masih belum berakhir.

Fisika merupakan ilmu yang berperan besar dalam mempelajari kondisi alam yang sedang terjadi di lingkungan sekitarnya. Ilmu ini berperan penting dalam kehidupan alam sebab adanya permasalahan alam seperti polusi, pemanasan global juga pemanfaatan sumber daya alam (Napitupulu,2015). Oleh sebab itu ilmu fisika harus dipahami supaya tidak ada penyalahgunaan sumber daya alam yang akan berakibat buruk. Pembelajaran dapat mengarahkan siswa untuk bereksplorasi secara bebas agar mencari tahu berbagai informasi. Sehingga siswa akan mempunyai pengalaman yang luas tentang lingkungan dan alam sekitarnya. Bereksplorasi dengan alam sekitar serta dengan praktikum secara langsung akan memudahkan siswa dalam memahami materi yang dipelajari. Kegiatan praktikum di laboratorium tidak hanya dapat memudahkan siswa dalam memahami materi, tetapi juga dapat membuat siswa tidak bosan dalam kegiatan praktikum. Namun dengan adanya wabah Covid-19 membuat praktikum tidak bisa dilaksanakan secara langsung. Tetapi ada satu cara untuk tetap melaksanakan praktikum di masa pandemi yaitu menggunakan media praktikum secara online atau disebut dengan laboratorium virtual (Sugiharti,S.;Sugandi,M.K, 2020)

\section{Metodologi}

Desain penelitian yang digunakan adalah penelitian kualitatif deskriptif. Pendekatan kualitatif berarti mengumpulkan data-data dari dokumen pribadi, naskah wawancara maupun dari dokumen resmi lainnya. Adapun metode pengumpulan data yang digunakan dalam penelitian ini adalah metode survei. Menurut Moch Nazir (2003) metode survei ini merupakan penelitian atau penyelidikan yang dilakukan untuk memperoleh data sesuai fakta-fakta yang terjadi. Penelitian ini dilaksanakan di wilayah kabupaten Garut pada tanggal 17 Agustus-17 September 2021. Data diperoleh dengan menyebarkan angket berbentuk google from yang berisi pertanyaan-pertanyaan tentang penelitian. Selanjutnya data yang telah terkumpulkan dianalisis. Tabel.1 disajikan indikator dalam kuesioner:

Tabel.1 Indikator Pertanyaan

\begin{tabular}{cl}
\hline No. & \multicolumn{1}{c}{ Indikator Pertanyaan } \\
\hline 1. & Pelaksanaan pembelajaran daring \\
\hline 2. & Pelaksanaan praktikum di masa pandemik \\
\hline 3. & Penggunaan laboratorium Virtual \\
\hline 4. & Pelaksanaan praktikum Virtual \\
\hline 5. & Kendala yang dihadapi siswa \\
\hline 6. & Kendala yang dihadapi guru \\
\hline 7. & Pengaruh praktikum virtual \\
\hline
\end{tabular}




\begin{tabular}{cl}
\hline No. & \multicolumn{1}{c}{ Indikator Pertanyaan } \\
\hline 8. & Pengalaman belajar praktikum virtual \\
\hline 9. & Saran Guru dan siswa \\
\hline 10. & Solusi pembelajaran daring \\
\hline
\end{tabular}

Adapun skema penelitian yang dilakukan disajikan pada Gambar 1 berikut:

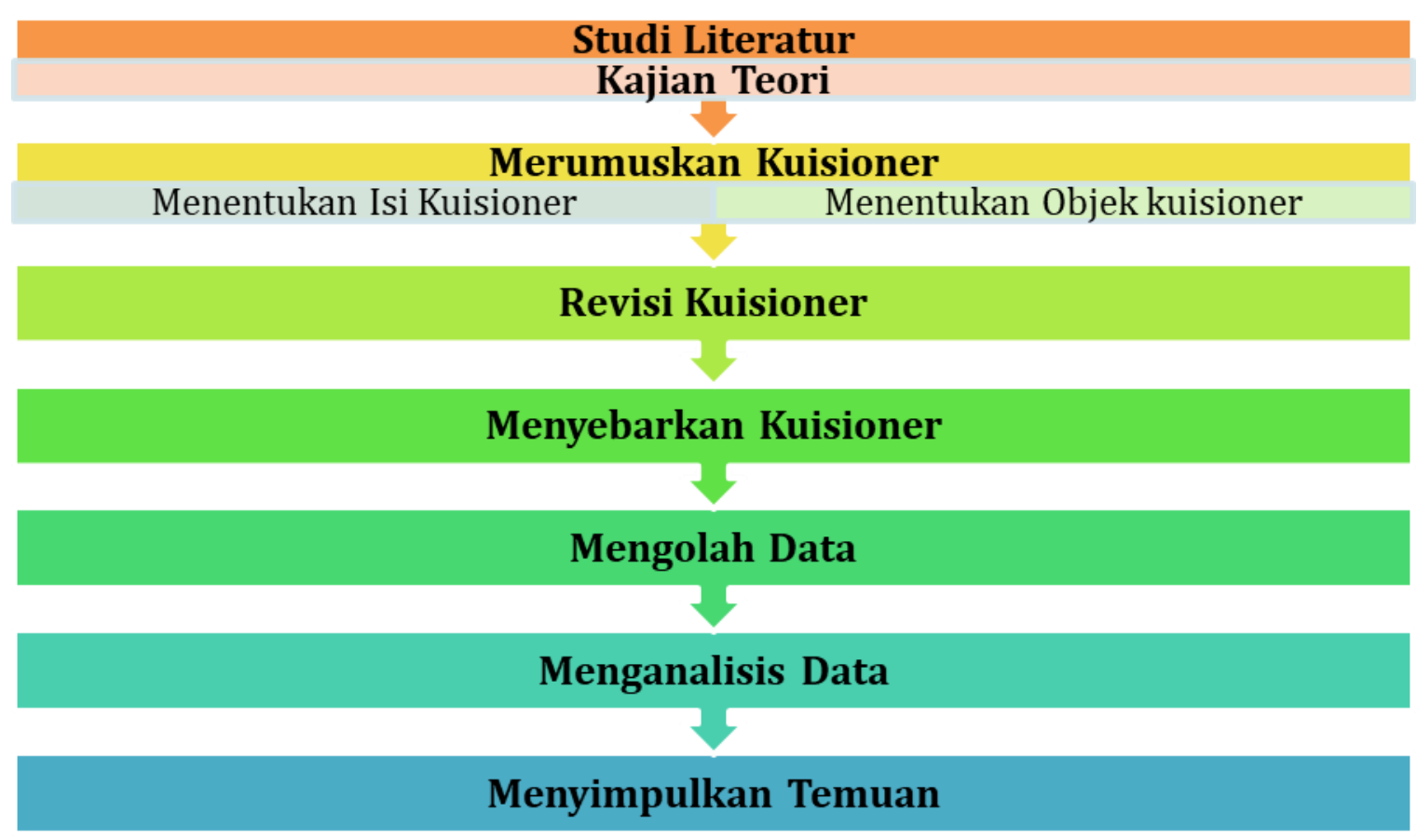

Gambar 1. Skema Penelitian

\section{$3 \quad$ Hasil dan Pembahasan}

Di abad ke-21 ini perkembangan dari segi gaya hidup terus berubah ke arah yang lebih praktis dan semakin kompleksnya suatu alat bantu demi keberlangsungan hidup manusia. Dengan kecanggihan dan kemajuan IPTEK dalam proses pembelajaran pun semakin mudah untuk diakses dengan kehadiran bermacam-macam alat elektronik penunjang pembelajaran, seperti handphone, laptop, tablet, komputer, dan lain sebagainya. Tidak hanya perangkat keras saja yang beragam bentuk dan fungsi, namun terdapat perangkat lunak yang membuat perangkat keras tersebut semakin kompleks dalam kegunaannya, seperti jaringan, aplikasi untuk komputer maupun handphone, dan jenis lainnya (Andi dkk, 2021). Berdasarkan, gambar 2, gambar 3 dan gambar 4. Ditemukan fakta bahwa pandemi ini membawa banyak perubahan pada setiap sektor kehidupan, Terutama pada bidang pendidikan dan proses belajar mengajar. Tidak sedikit lembaga sekolah yang merasa kebingungan untuk menyesuaikan pelaksanaan pembelajaran di masa pandemi seperti ini, terlebih keadaan sekolah yang memang berada di pelosok dan kesulitan untuk mengakses informasi. Namun disamping itu, perkembangan teknologi di zaman ini berkembang dengan sangat pesat, dan hal ini bisa kita rasakan sekarang.

Di masa pandemi ini, merujuk pada perkembangan teknologi dan penerapan proses belajar secara daring, ide, inovasi dan keterampilan tenaga pendidik mulai dikembangkan. Melihat betapa berharganya sebuah pendidikan untuk seorang siswa yang sedang dalam masa pertumbuhan. Dalam prosesnya, tidak sedikit siswa yang kurang mengerti akan pelajaran yang diberikan oleh gurunya terlebih pada mata pelajaran eksak dan juga sains. Seperti halnya pelajaran Fisika. Fisika merupakan mata pelajaran yang membutuhkan ruang untuk bisa melakukan eksperimen dan percobaan agar supaya siswa itu paham akan pelajaran yang di 
sampaikan. Dan akhirnya, sebagai upaya pemanfaatan teknologi dan juga mempermudah proses belajar siswa semua ide dikerahkan yang kemudian salah satunya munculnya sistem belajar menggunakan Laboratorium Virtual. Praktikum yang seharusnya dilaksanakan secara langsung oleh siswa dengan objek pengamatannya kini mulai dikembangkan melalui Laboratorium Virtual ini. akhirnya hal ini menarik kami untuk melakukan pengamatan dan menuliskannya dalam sebuah artikel sebagai acuan dan bahan evaluasi dalam perkembangan pembelajaran dimasa pandemi.

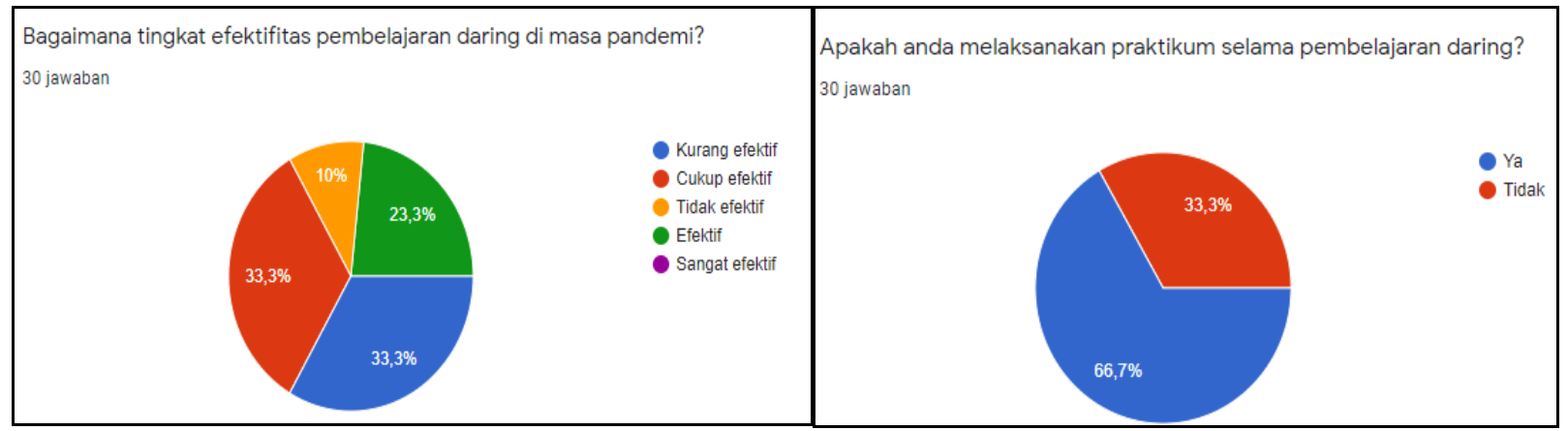

Gambar 2. Efektivitas Pembelajaran Daring

Gambar 3. Kegiatan Praktikum selama

Pembelajaran Daring

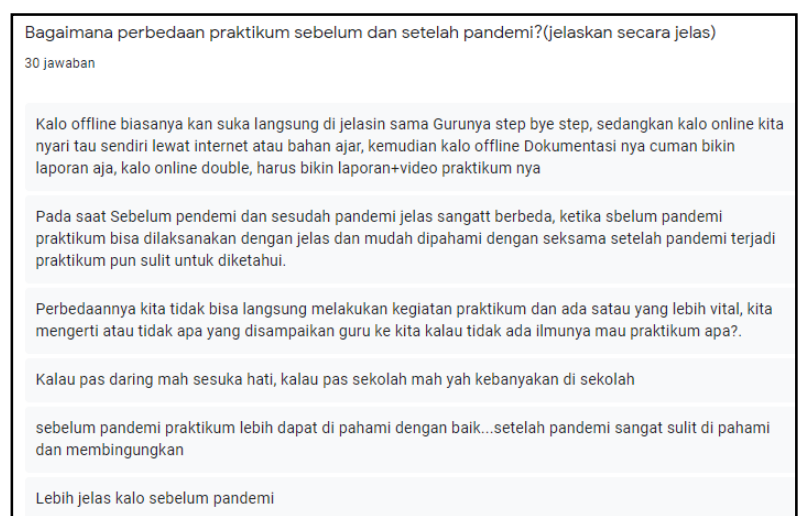

Gambar 4. Pernyataan Responden

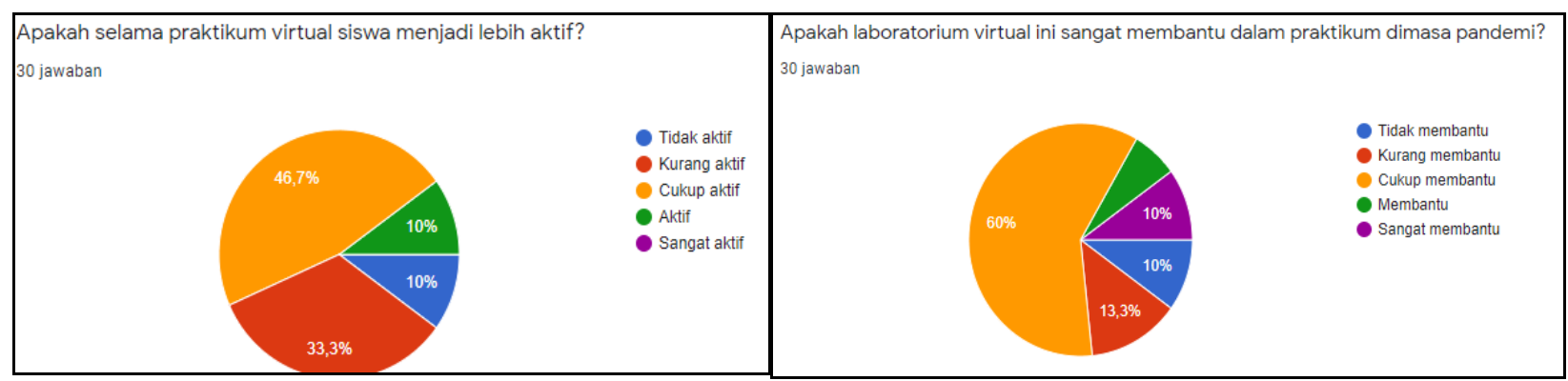

Gambar 5 Keaktifan Siswa pada

Pembelajaran Daring
Gambar 6. Peran Lab Virtual saat

Pandemi

Laboratorium Virtual bermula dari sebuah proyek yang bernama "Essays and Resources on the Experimentalization of Life (1830-1930) yang berlokasi di Max Planck Institute for the History Science. Proyek ini bertujuan untuk meneliti sejarah tentang experimentalization of life. Istilah experimentalization menjelaskan interaksi antara ilmu kehidupan, seni, arsitektur, media dan teknologi dalam paradigma eksperimen. Platform dari Laboratorium virtual tersebut tidak hanya tentang topik tersebut di atas, melainkan 
juga berperan sebagai lingkungan penelitian untuk penelitian-penelitian yang baru (Wikipedia, 2010; Ratih, 2011)

Bisa kita lihat dan kaji bersama dalam diagram di atas, bahwa 100\% dari beberapa sekolah yang kami amati, mereka secara keseluruhan melakukan proses belajar secara daring. Namun mereka juga merasakan dampak dari berubahnya sistem belajar. Mereka mengatakan bahwa belajar secara daring ini kurang efektif untuk sebagian kalangan terlebih untuk melakukan praktikum secara online, dikarenakan ada beberapa faktor tidak memungkinkan. Di sini kita juga bisa lihat bagaimana tanggapan siswa dan guru mengenai penerapan laboratorium virtual. Terekap $80 \%$ siswa dan guru yang mengetahui dan paham apa itu Laboratorium Virtual. Dari data yang kami dapatkan, diketahui bahwa hampir semua sekolah menerapkan proses praktikum secara online melalui penggunaan laboratorium virtual.

Kemudian kami juga memperoleh data mengenai respons bagaimana proses penggunaan laboratorium virtual pada saat belajar di rumah. Responden mengungkapkan bahwa laboratorium virtual dianggap sistem yang kurang efektif untuk memberikan pemahaman kepada siswa, dan menurut mereka Video demonstrasi pembelajaran dianggap langkah yang lebih efektif untuk memberikan Pemahaman yang lebih kepada siswa karna dengan seperti itu Materi yang kurang dimengerti Siswa dapat diulang dan putar kembali video demonstrasinya. Dari hasil observasi yang kami lakukan melalui penyebaran angket, didapatkan bahwa 46,7\% siswa dan guru merasa efektif dengan adanya sistem laboratorium virtual ini, berbeda tipis dengan persentase nilai kurang efektif. Hai ini di dasarkan pada jaringan, waktu dan kondisi siswa yang menjadikannya kurang efektif. Singkatnya penggunaan laboratorium virtual di masa pandemi ini menjadi salah satu alternatif yang lumayan baik untuk mendorong keberlangsungan belajar. Setelah mengetahui tentang keefektifannya, lalu apakah laboratorium virtual ini membantu siswa?, hasil dari data yang telah di kumpulkan, cukup membantu di angka tertinggi dengan perolehan nilai $60 \%$ sangat membantu $10 \%$ kurang membantu $10 \%$ dan tidak membantu $13.3 \%$,karena di masa pandemi sekarang kita di harus kan untuk belajar di rumah, maka dengan dilaksanakannya laboratorium virtual cukup membantu para siswa. Gambar 7 dan 8 menyajikan intensitas penggunaan virtual lab.

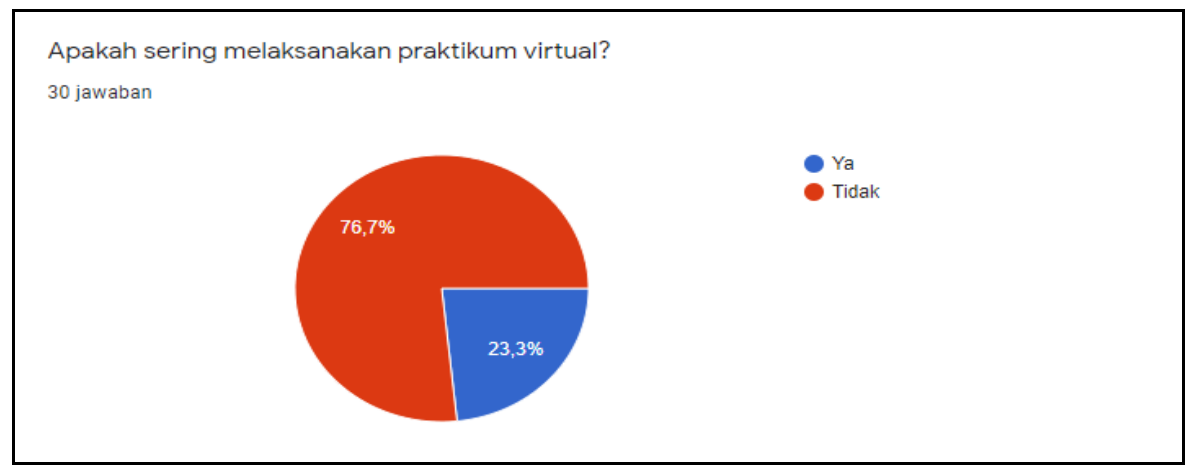

Gambar 7. Intensitas Penggunaan lab Virtual

Media labolatorium virtual apa yang sering digunakan?

30 jawaban

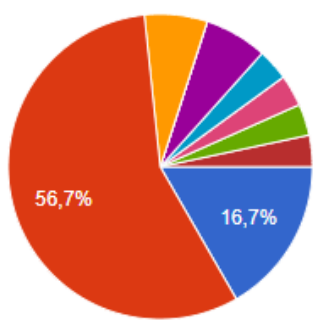

Phet

YouTube

JavaScript virtual lab

Falsh

Zoom

Belum pernah

Zoom Meeting, Google Classroom,

LMS.

Tidak Ada

Kan tidak kenapa masih nanya

Gambar 8. Jenis Media yang Sering Digunakan 
Berdasarkan gambar 7 menjelaskan bahwa 76,7\% responden menjawab tidak melaksanakan praktikum virtual. Sedangkan, 23,3\% responden menjawab pernah melakukan praktikum virtual. Di masa pandemi covid-19 ini praktikum sulit untuk dilaksanakan karena adanya keputusan pemerintah tentang pembelajaran yang dilakukan dengan jarak jauh atau online. Maka, praktikum juga harus dilaksanakan secara online atau disebut dengan praktikum virtual. Akan tetapi dengan melaksanakan praktikum virtual ini banyak keterbatasan seperti keterbatasan dalam tata cara melaksanakan praktikum virtual, keterbatasan internet bagi peserta didik yang di daerahnya internet kurang memadai, tanpa ada internet praktikum virtual tidak dapat dilaksanakan serta keterbatasan praktikum virtual itu tidak bisa memberikan pengalaman yang nyata, hanya dapat melaksanakan dengan media saja (Rr. Yuliana Rachmawati Kusumaningsih ;Catur Iswahyudi ;Erma Susanti, 2014).

Gambar 8 menjelaskan bahwa kebanyakan peserta didik menggunakan Youtube untuk media laboratorium virtual yaitu sebesar 56,7\% responden. Sedangkan sebanyak 16,7\% menggunakan phet dan sisanya 26,6\% responden ada yang menggunakan java script, fals, zoom juga ada yang tidak pernah melakukan laboratorium virtual ini. Media untuk melaksanakan laboratorium virtual ini harus media yang membuat peserta didik nyaman dan mudah memahami. Jika dilihat ,banyak responden yang memilih youtube sebagai media, karena dalam Youtube Video praktikumnya dapat diulang beberapa kali, bila mana tidak mengerti bisa diulang Kembali sampai mengerti. Praktikum virtual dapat digunakan sebagai media pembelajaran mandiri untuk peserta didik (Mahdini et al., 2014).

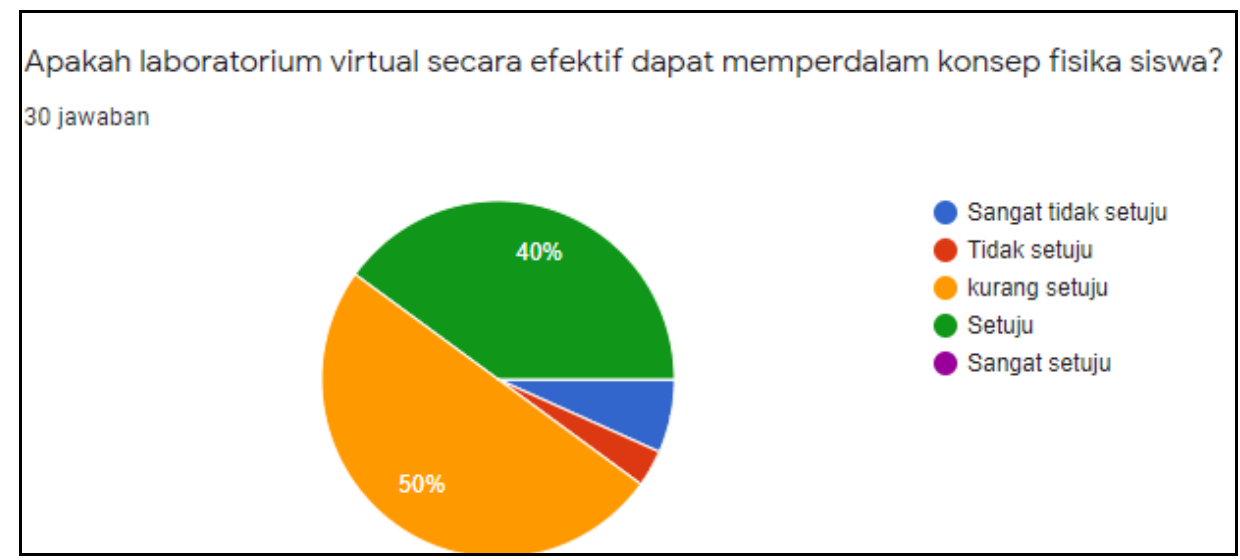

Gambar 9. Efektifitas Lab Virtual dalam Kegiatan Pembelajaran Fisika

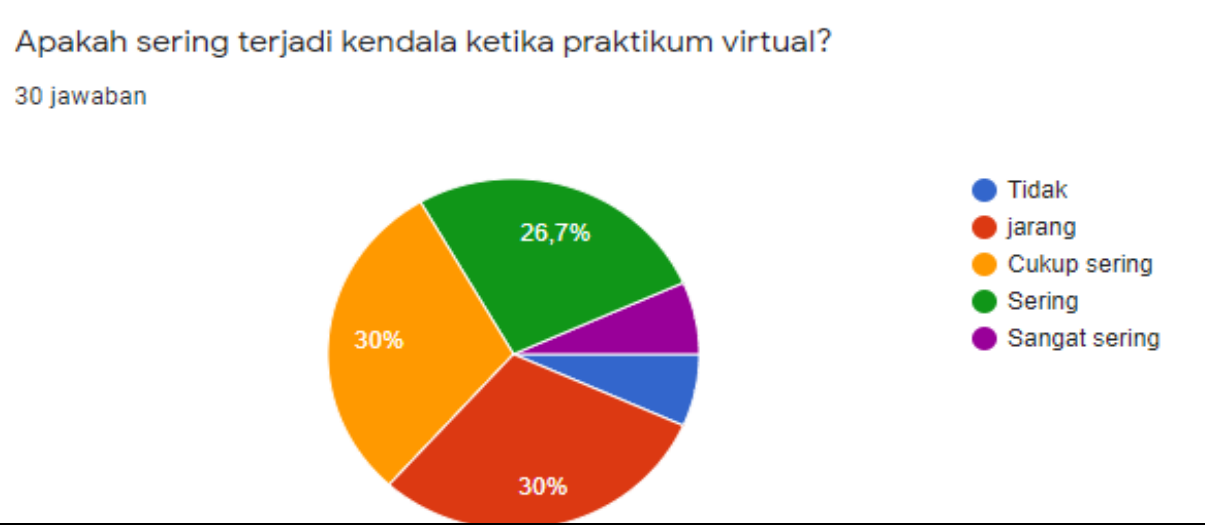

Gambar 10. Kendala Penggunaan Lab Virtual 


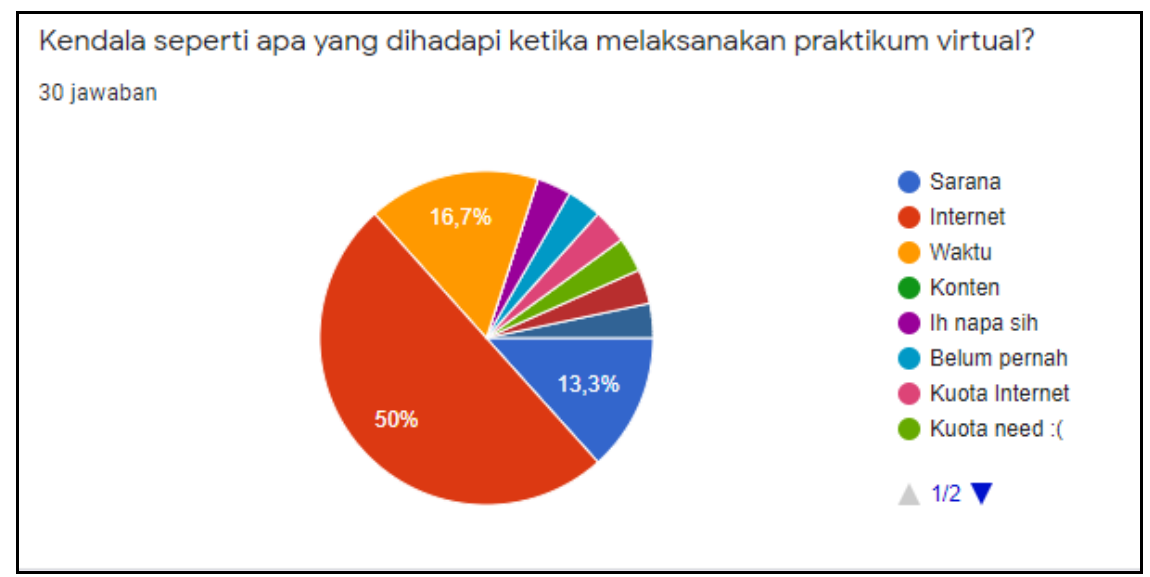

Gambar 11. Kendala Lab Virtual

Berdasarkan grafik pada gambar 9 menjelaskan bahwa 50\% responden kurang setuju bahwa laboratorium virtual dapat memperdalam konsep fisika.Sedangkan, $40 \%$ responden setuju dengan adanya laboratorium virtual yang dapat memperdalam konsep fisika. Fisika tidak dapat lepas dari adanya suatu eksperimen, karena fisika mempelajari ilmu alam. Pada gambar 10, dipaparkan bahwa terdapat kendala dalam praktikum virtual $30 \%$ responden sering terkendala,30\% cukup sering terkendala,26,7\% dan ada juga yang tidak ada kendala dalam melaksanakan praktikum virtual. Berdasarkan gambar 6 kendala praktikum yang sering terjadi yaitu pada internet. Dari gambar 11 dapat dilihat bahwa 50\% responden mengalami kendala dalam melaksanakan praktikum virtual itu adalah internet. Tidak dapat di mungkiri bahwa internet memang kendala yang paling sering terjadi karena banyak keterbatasan seperti kuota habis, jaringan jelek, dan yang lainya. Adapun 16,7\% responden terkendala karena waktu, Dalam melaksanakan praktikum memang memerlukan waktu yang lumayan lama. Sebuah praktikum yang bagus itu ketika melaksanakannya dengan teliti. Kebanyakan responden untuk mengatasi kendala-kendala pada saat praktikum virtual itu adalah dengan berusaha mencari internet dengan jaringan yang bagus seperti berpindah tempat. Adapun juga kendala dalam sarana yaitu kendala ketika menggunakan aplikasi PHET. Kendala tersebut di sebabkan panduan praktikum gelombang PhET kurang memadai, kemudian akibat terbatasnya fitur percobaan PhET dan akibat keterbatasan bahasa (Ulfah, R. Y., Yuliani, H., \& Nastiti, L. R. ;2020)

\section{Kesimpulan}

Pendidikan merupakan salah satu bidang yang sangat berpengaruh di dunia, dengan adanya pendidikan manusia mampu mengendalikan dirinya menjadi manusia yang berkarakter dan berkualitas. Pada awal tahun 2019 sebuah wabah yang menyebar datang dari Wuhan China telah mengubah keadaan dan semua tatanan kehidupan sehingga memasuki era New Normal. Dampak dari adanya penyebaran wabah ini yang dapat kita rasakan salah satunya dalam bidang pendidikan. Sistem belajar mengajar pun beralih menjadi sistem belajar secara online. Tidak mudah memang untuk sebuah lembaga pendidikan menyesuaikan Sistem belajar dan beradaptasi dengan keadaan. Laboratorium virtual merupakan salah satu alternatif metode pembelajaran di era Pandemi yang menunjang untuk tetap berlangsungnya proses Pembelajaran berbasis praktikum pada mata pelajaran sains. Hal ini yang memberikan motivasi kepada kami untuk melakukan sebuah pengamatan sederhana mengenai respons Siswa dan guru terhadap penggunaan laboratorium virtual.

Berdasarkan hasil pengamatan yang kami lakukan , ditemukan bahwa Teknologi yang berkembang saat ini banyak membawa pengaruh besar pada kehidupan. Begitu pun dengan proses penggunaan laboratorium virtual. Guru dan siswa beranggapan bahwa laboratorium virtual yang diterapkan di sekolah dapat membantu proses pembelajaran di sekolah. Namun tidak sedikit juga yang mengeluhkan ketidakefektifan dari Laboratorium Virtual ini, disebabkan kurangnya pemahaman terhadap prosedur kerja secara online, waktu yang dianggap singkat untuk dapat memahami materi pada praktikum tersebut dan juga ketidakstabilan akses internet yang terkadang terganggu oleh cuaca dan sebagainya. Namun disamping itu, dengan adanya laboratorium virtual ini kegiatan belajar masih bisa berjalan dengan baik dan sedikit mengurangi 
permasalahan yang ada di Dunia pendidikan kita, dengan laboratorium virtual ini masyarakat, siswa maupun guru bisa mengembangkan potensi, ide, dan inovasi-inovasi yang baru dengan memanfaatkan teknologi yang ada.

\section{Daftar Pustaka}

Asmuni, A. (2020). Problematika Pembelajaran Daring di Masa Pandemi Covid-19 dan Solusi Pemecahannya. Jurnal Paedagogy, 7(4), 281-288.

Jamaluddin, D., Ratnasih, T., Gunawan, H., \& Paujiah, E. (2020). Pembelajaran daring masa pandemik Covid-19 pada calon guru: hambatan, solusi dan proyeksi. $L P 2 M$.

Kusumaningsih, Y. R., Iswahyudi, C., \& Susanti, E. (2014, November). Pengembangan model laboratorium virtual sebagai solusi keterbatasan sumber daya pembelajaran. In Prosiding Seminar Nasional Aplikasi Sains \& Teknologi (SNAST), Yogyakarta.

Muhajir, S. N., Lestari, P. R., \& Rahayu, N. S. (2021). Tingkatan Literasi Sains Mahasiswa Calon Guru Fisika. Jurnal Pendidikan UNIGA, 15(1), 378-384.

Napsawati, N. (2020). Analisis situasi pembelajaran IPA Fisika dengan metode daring di tengah wabah covid-19. Karst: jurnal pendidikan fisika dan terapannya, 3(1), 6-12.

Nova, D. A. O., Dwikoranto, D., \& Lestari, N. A. (2021). ANALISIS PERSEPSI SISWA TERHADAP PEMBELAJARAN FISIKA BERBASIS ECOPEDAGOGY DENGAN METODE DARING SELAMA PANDEMI COVID-19. ORBITA: Jurnal Kajian, Inovasi dan Aplikasi Pendidikan Fisika, 7(1), 19-26.

PUTRI, A., Muslim, M., \& Wiyono, K. (2018). PENGEMBANGAN LABORATORIUM VIRTUAL MATERI GERAK PARABOLA UNTUK SMA/MA (Doctoral dissertation, Sriwijaya University).

Sugiharti, S., \& Sugandi, M. K. (2020, November). Laboratorium Virtual: Media Praktikum Online Untuk Meningkatkan Pemahaman Siswa Di Masa Pandemi. In Prosiding Seminar Nasional Pendidikan (Vol. 2, pp. 45-51).

Suryanda, A., Rusdi, R., \& Kusumawati, D. (2017). Pengembangan Praktikum Virtual Urinalisis Sebagai Media Pembelajaran Biologi Siswa SMA Kelas XI. Biosfer: Jurnal Pendidikan Biologi, 10(1), 1-8.

Tim Kerja Kementerian dalam Negeri, (2020). Tersedia online https://covid19.go.id/p/panduan/kemendagripedoman-umum-menghadapi-pandemi-covid-19-bagipemerintah-daerah diakses pada November 2021

Ulfah, R. Y., Yuliani, H., \& Nastiti, L. R. (2020, November). Kendala Mahasiswa Dalam Menggunakan Simulasi Virtual Phet Pada Pembelajaran Praktikum Gelombang Selama Pandemi Covid-19. In SNPF (Seminar Nasional Pendidikan Fisika).

Wikipedia, 2010, "Virtual laboratory", http://en.wikipedia.org/wiki/Virtual-_Laboratory 